\title{
Broca's aphasia due to cerebral venous sinus thrombosis following chemotherapy for small cell lung cancer: A case report and review of literature
}

\author{
TOLGA TUNCEL ${ }^{1}$, ALPASLAN OZGUN ${ }^{1}$, LEVENT EMIRZEOĞLU ${ }^{1}$, \\ SERKAN CELIK $^{1}$, SERKAN DEMIR ${ }^{2}$, OGUZ BILGI ${ }^{1}$ and BULENT KARAGOZ ${ }^{1}$ \\ Departments of ${ }^{1}$ Medical Oncology and ${ }^{2}$ Neurology, Gata Haydarpasa Training Hospital, Istanbul 34668, Turkey
}

Received January 11, 2014; Accepted September 26, 2014

DOI: $10.3892 / \mathrm{ol} .2014 .2709$

\begin{abstract}
Cancer is associated with an increased risk of cerebrovascular incidents and treatment with chemotherapy enhances that risk further. Brocha's aphasia is a stroke-related syndrome, the presentation of which has been rarely reported during cisplatin-based chemotherapy. The current study presents the case of a 27-year-old male with advanced-stage small cell lung cancer. The patient developed Broca's aphasia following cisplatin-based chemotherapy.
\end{abstract}

\section{Introduction}

Broca's aphasia is a condition resulting from damage to speech areas in the left hemisphere (1). It is easily distinguished by experienced clinicians from other types of aphasia, such as Wernicke's, global and conduction aphasia; however, the prognosis of patients with Broca's aphasia remains poor (2). Cerebral venous sinus thrombosis (CVST) is a rare condition, accounting for $0.5-1 \%$ of all strokes and can cause Broca's aphasia (2). It mostly presents as a seizure, intracranial hypertension syndrome, isolated headache and focal lobar syndrome (3). Diagnosis of CVST is usually based on the presence of thrombi in the cerebral sinuses and/or veins on veno computed tomography or magnetic resonance venography (4). Cisplatin is an antineoplastic agent and has been associated with cerebrovascular incidents (5). Although the exact mechanism of cisplatin-induced thromboembolic events is not currently well understood, direct vascular toxicity, apoptosis, endothelial dysfunction, hypomagnesemia and tumour embolisation are possible risk factors (6). The current study presents the case of a young male patient with advanced-stage small cell lung

Correspondence to: Dr Tolga Tuncel, Department of Medical Oncology, Gata Haydarpasa Training Hospital, Tibbiye Street, Uskudar, Istanbul 34668, Turkey

E-mail: dr_tolgatuncel@hotmail.com

Key words: Broca's aphasia, sinus venous thrombosis, cisplatin, lung cancer cancer who developed Broca's aphasia following cisplatin-based chemotherapy, and also reviews the literature surrounding similar cases. Written informed consent was obtained from the patient.

\section{Case report}

A 27-year old male presented to the Department of Medical Oncology, Gata Haydarpasa Training Hospital (Istanbul, Turkey) with Broca's aphasia and general seizures. The patient had been diagnosed with advanced-stage small cell lung cancer two months previously. Baseline magnetic resonance imaging (MRI) of the patient was normal (Fig. 1). The patient received $135 \mathrm{mg}$ cisplatin on day one and $180 \mathrm{mg}$ etoposide on days one to three. On day six of the second cycle, the patient was admitted to the emergency department $4 \mathrm{~h}$ following the onset of a stroke. The MRI scan revealed a CVST in the left transverse sinus, as well as in the left sigmoid sinus with venous infarct (Fig. 2). Laboratory analysis showed a normal coagulation profile (activated partial thromboplastin time, $34.5 \mathrm{sec}$; normal range, $25-38 \mathrm{sec}$; international normalized ratio, 1.048; normal range, 0.8-1.2), and serum magnesium levels ( $2 \mathrm{mg} / \mathrm{dl}$; normal range, $1.2-2.5 \mathrm{mg} / \mathrm{dl}$ ), platelet count $\left(204,000 / \mathrm{mm}^{3}\right.$; normal range, $150,000-450,000 /$ $\mathrm{mm}^{3}$ ) and lipid profiles (triglycerides: $116 \mathrm{mg} / \mathrm{dl}$; normal range, $40-160 \mathrm{mg} / \mathrm{dl}$ ) were also normal. Echocardiography for embolic sources and electrocardiography for arrhythmia were normal. The patient was subjected to anticoagulation therapy with low molecular weight heparin and speech therapy was commenced. The symptoms resolved completely within one month and cisplatin-etoposide chemotherapy was continued in addition to the anticoagulation therapy.

\section{Discussion}

Chemotherapy leads to an increased risk of thromboembolic complications in germ cell, urethral, head and neck and breast cancer, lymphoma and leukemia $(7,8)$. Venous thromboembolic events are observed more frequently than arterial thromboembolic events. Weijl et al (7) reported that germ cell cancer patients who receive cisplatin-based chemotherapy, particulary those who receive high doses of corticosteroids or have liver metastases, are at considerable risk of developing 
Table I. Previously reported cases of cerebral venous sinus thrombosis following cisplatin-based chemotherapy.

\begin{tabular}{|c|c|c|c|c|c|c|c|}
\hline $\begin{array}{l}\text { First author } \\
\text { (year) [ref] }\end{array}$ & $\begin{array}{l}\text { Age, years } \\
\text { /gender }\end{array}$ & Tumor & Chemotherapy & Symptoms & Imaging & Site & Treatment \\
\hline Unal (2008) [10] & $16 / \mathrm{F}$ & $\begin{array}{l}\text { Ewing } \\
\text { sarcoma }\end{array}$ & $\begin{array}{l}\text { Cis+Ifo+ } \\
\text { Adr+Vin }\end{array}$ & $\begin{array}{l}\text { Headache } \\
\text { diplopia ptosis }\end{array}$ & MR MRA & SSSTS & LMWH \\
\hline Karam (2008) [11] & $33 / \mathrm{M}$ & $\begin{array}{l}\text { Germ-cell } \\
\text { carcinoma } \\
\text { of the testis }\end{array}$ & Cis+Eto & $\begin{array}{l}\text { Headache, } \\
\text { partial seizures }\end{array}$ & $\mathrm{MR}, \mathrm{CA}$ & $\begin{array}{l}\text { SSS } \\
\text { RLS }\end{array}$ & $\begin{array}{l}\text { Anticoagulant } \\
\text { sodium valproate }\end{array}$ \\
\hline Karam (2008) [9] & $60 / \mathrm{F}$ & $\begin{array}{l}\text { PDP } \\
\text { carcinoma }\end{array}$ & $\begin{array}{l}\text { Cis }+5 \\
\text { Fluorouracil }\end{array}$ & $\begin{array}{l}\text { Headache, } \\
\text { partial seizures }\end{array}$ & $\mathrm{MR}, \mathrm{CA}$ & $\begin{array}{l}\text { SSS } \\
\text { RLS }\end{array}$ & $\begin{array}{l}\text { Heparin, } \\
\text { clopidogrel } \\
\text { sodium valproate }\end{array}$ \\
\hline Papet (2011) [12] & 47/M & $\begin{array}{l}\text { Embryonal } \\
\text { carcinoma }\end{array}$ & Cis+Eto+Ble & $\begin{array}{l}\text { Headache, } \\
\text { weakness in } \\
\text { left limbs }\end{array}$ & MR & $\begin{array}{l}\text { SSS } \\
\text { SS } \\
\text { TS }\end{array}$ & Anticoagulant \\
\hline Papet (2011) [12] & 29/M & $\begin{array}{l}\text { Embryonal } \\
\text { carcinoma }\end{array}$ & Cis + Eto+Ble & $\begin{array}{l}\text { Headache, } \\
\text { general seizure }\end{array}$ & $\mathrm{CT}$ & SSS & LMWH \\
\hline
\end{tabular}

F, female; Cis, cisplatin; Ifo, ifosfomid; Adr, adriamycine; MR, magnetic resonance; MRA, magnetic resonance angiography; SSS, superior sagittal sinus; TS, transverse sinus; LMWH, low molecular weight heparin; M, male; Eto, etoposide; RLS, right lateral sinus; CA, conventional angiography; PDP, poorly differentiated pericardial carcinoma; Ble, bleomycin; SS, sigmoid sinus.
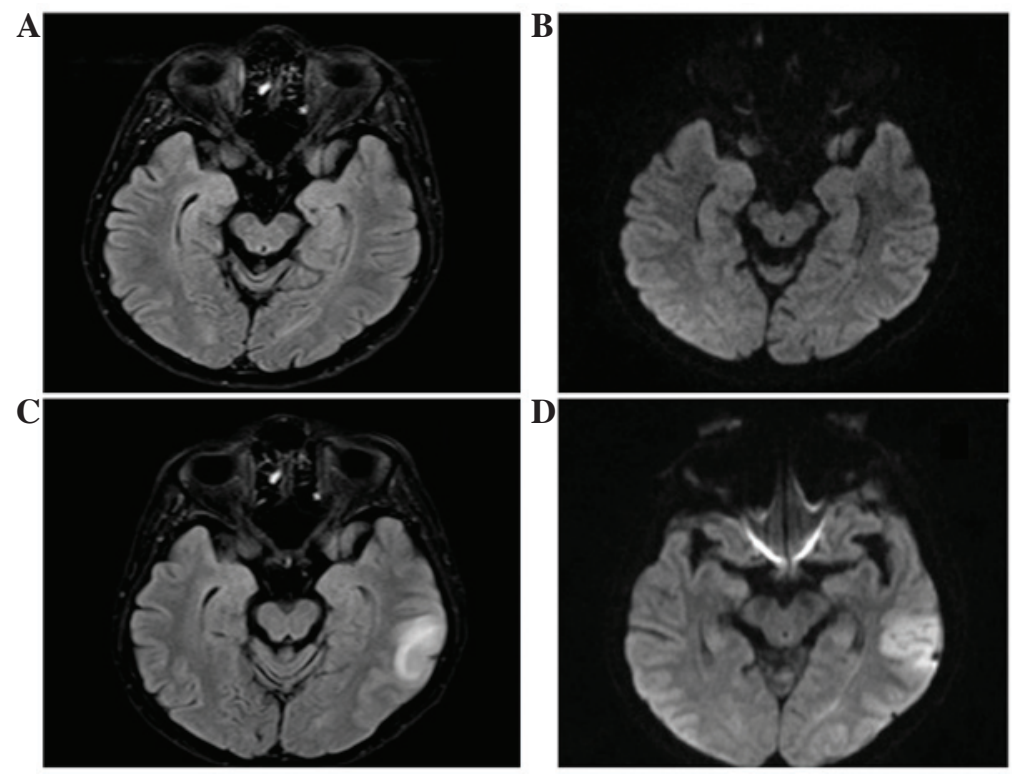

Figure 1. (A and B) Normal cranial magnetic resonance imaging and (C and D) flair and diffusion weighted images showing acute left parietal infarction.
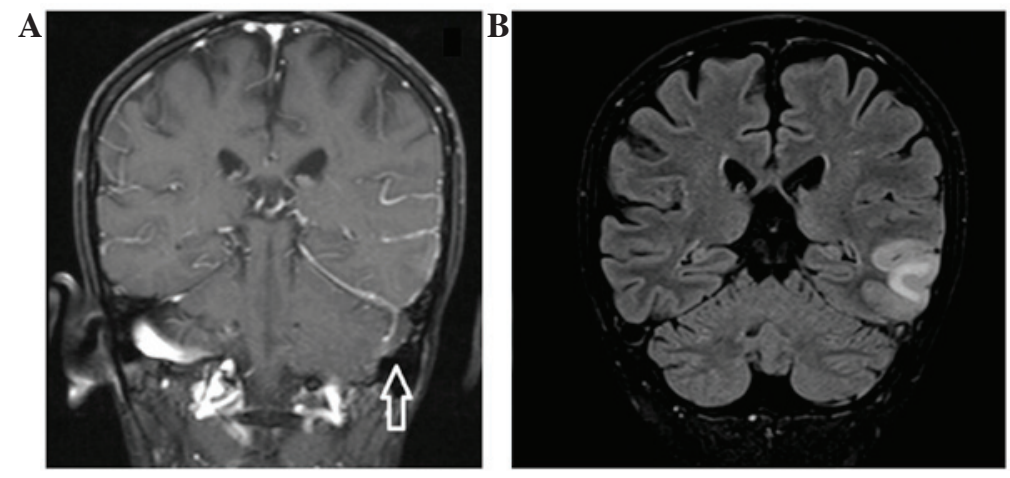

Figure 2 (A) Contrast enhanced coronal T1 weighted imaging shows left transverse sinus thrombosis and (B) flair coronal sequence shows infarction. 
thromboembolic events. Prophylactic administration of heparin may be considered in this group. Li et al (8) reviewed 10,963 patients and reported that the risk of ischemic stroke stroke after chemotherapy is predicted by the use of cisplatin-based chemotherapy, not cancer histological type. The worldwide incidence of venous thromboembolic events during cisplatin-based chemotherapy for a various advanced solid tumors is $1.92 \%$ (10). We reviewed the literature with respect to CVST occurring in cisplatin-based chemotherapy. To date, very few cases of patients with CVST following cisplatin-based chemotherapy have been reported (Table I) (11-13) and to the best of our knowledge, this is the first report of Broca's aphasia and CVST associated with a cisplatin-based chemotherapy regimen.

The patient in the current study presented with Broca's aphasia due to a CVST in the left transverse sinus, following cisplatin-based chemotherapy. Increased von Willebrand factor, hypomagnesemia and damage to the vascular endothelium are known risk factors for the cisplatin-associated vascular toxicity. Chemotherapy-induced venous thrombosis usually develops within 10 days following the most recent chemotherapy cycle and $63 \%$ of cases occurred following the first cycle (9). CVST is rare condition responsible for approximately 1-2\% of all cerebral strokes (14). The clinical presentation of CVST is highly variable and non-specific; symptoms including headaches, nausea and vomiting, visual disturbances, aphasia, coma and seizure may be observed in CVST. The treatment of this condition ranges from anticoagulation with intravenous heparin or subcutaneous low-molecular-weight heparin, to endovascular thrombectomy or thrombolysis. To date, there are no evidence-based guidelines on prophylaxis of thromboembolic events in cancer patients that are treated with cisplatin-based chemoterapy. Prophylactic heparin may be used in patients with curable germ cell tumors and early stage of lung cancer. The aim of this study was to increase the awareness of the possibility of CVST in patients with lung cancer treated with cisplatin-based chemotherapy.

In conclusion, the possibility of Broca's aphasia and CVST in patients with lung cancer, receiving platinum-based chemotherapy, must be considered when determining the differential diagnosis. Broca's aphasia is a fatal and rare complication, but can be treated successfully with low-molecular-weight heparin. An accurate diagnosis of CVST may be determined using MRI. To date, there are no evidence-based guidelines for the prophylaxis of thromboemboli in cancer; for patients with a history of thromboembolism, the concomitant use of low-molecular-weight heparin and acetylsalicylic acid during each cycle of cisplatin-based chemotherapy must be considered (15).

\section{References}

1. Burns MS and Fahy J: Broca's area: rethinking classical concepts from a neuroscience perspective. Top Stroke Rehabil 17: 401-410, 2010.

2. Bousser MG and Ferro JM: Cerebral venous thrombosis: an update. Lancet Neurol 6: 162-170, 2007.

3. Fridriksson J, Fillmore P, Guo D and Rorden C: Chronic Broca's aphasia is caused by damage to Broca's and Wernicke's areas. Cereb Cortex: July 11, 2014 (Epub ahead of print).

4. Ferro JM and Canhão P: Cerebral venous sinus thrombosis: update on diagnosis and manangement. Curr Cardiol Rep 16: $523,2014$.

5. Karagoz B, Bilgi O, Akyol I, Ozgun A, Turken $\mathrm{O}$ and Kandemir EG: Cerebrovasculer accident after chemotherapy for testicular cancer. Military medicine 174: 320-321, 2009.

6. Fernández-Domínguez J, García Rodríguez R, Valle Pereda $\mathrm{M}$ and Mateos Marcos V: Cerebral infarction after cisplatin-gemcitabine chemotherapy: probable cause-effect. Neurologia 27: 245-247, 2012.

7. Weijl NI, Rutten MF, Zwinderman AH, Keizer HJ, Nooy MA, Rosendaal FR, Cleton FJ and Osanto S: Thromboembolic events during chemotherapy for germ cell cancer: a cohort study and review of the literature. J Clin Oncol 18: 2169-2178, 2000 .

8. Li SH, Chen WH, Tang Y, Rau KM, Chen YY, Huang TL, Lis JS and Huang CH: Incidence of ischemic stroke post-chemotherapy: a retrospective review of 10,963 patients. Clin Neurol Neurosurg 108: 150-156, 2006.

9. Moore RA, Adel N, Riedel E, Bhutani M, Feldman DR, Tabarra NE, et al: High incidence or thromboembolic events in patients treated with cisplatin-based chemotherapy: a large retrospective analysis. J Clin Oncol 29: 3466-3473, 2011.

10. Seng S, Liu Z, Chiu SK, et al: Risk venous thromboembolism in patients with cancer treated with Cisplatin: a systematic review and meta-analysis. J Clin Oncol 30: 4416-4426, 2012.

11. Unal E, Yazar A, Koksal Y, Caliskan U, Paksoy Y and Kalkan E: Cerebral venous sinus thrombosis in an adolescent with Ewing sarcoma. Childs Nerv Syst 24: 983-986, 2008.

12. Karam C and Koussa S: Cerebral dural sinus thrombosis following cisplatin chemotherapy. J Clin Neurosci 15: 1274-1275, 2008.

13. Papet C, Gutzeit A and Pless M: Two cases of cerebral sinus venous thrombosis following chemotherapy for non-seminomatous germ cell tumor. Case Rep Oncol 4: 555-559, 2011.

14. Coutinho JM and Stam J: How to treat cerebral venous and sinus thrombosis. J Thromb Haemost 8: 877-883, 2010.

15. Etgen T, Weidenhöfer $\mathrm{G}$ and Kubin T: Cisplatin-associated occlusion of the internal carotid artery. Onkologie 32: 754-757, 2009. 